\title{
PERAN TEKNOLOGI DALAM IMPLEMENTASI STRATEGI MANUFAKTUR PADA PERUSAHAAN MANUFAKTUR DI INDONESIA: STUDI DENGAN PENDEKATAN KONTINGENSI
}

\author{
Lina Anatan \\ Universitas Maranatha Bandung
}

\begin{abstract}
Expanding global competition, rapidly changing market and technology, increasing complexity and uncertainty are creating a new competitive environment. To be successful in this globally competitive and rapidly changing environment, organization must formulate strategic plan that is consistent with their investment and technology. This research was conducted to investigate the relationship among manufacturing strategy, technology adoption, and firm performance. Data were collected through mailed questionnaires (525 questionnaires) and direct survey in 25 firms. The questionnaires were sent to 550 CEOs of manufacturing firm in Indonesia. A hundred and six responses returned and made a response rate of $19.27 \%$.

The study finds different results for hard and soft technology. Hard technology moderates the relationship between manufacturing strategy and operational performance, as a quasi moderator variable. On the other hand, soft technology has an impact on the manufacturing strategy-performance relationship as an independent predictor variable, but it does not moderate the relationship between manufacturing strategy and operational performance.
\end{abstract}

Keywords: manufacturing strategy, technology adoption, operational performance, technology

\section{PENDAHULUAN}

Kompleksitas lingkungan dan tantangan yang dihadapi perusahaan menuntut perusahaan untuk memperkuat kapabilitas teknologi dan kompetensi organisasi. Kompleksitas mempengaruhi cara pengembangan dan penyampaian produk dan jasa pada konsumen (Lagace dan Bourgault, 2003). Penggunaan teknologi menawarkan cara untuk memperbaiki desain produk, dikembangkan, dan dijual pada pasar industrial. Dalam lingkungan yang tidak pasti, kapasitas perusahaan untuk meningkatkan kehandalan dan melakukan perbaikan secara kontinyu baik dalam bisnis maupun proses manufaktur merupakan kondisi pokok untuk memastikan sustainabilitas dalam jangka panjang.

Teknologi menjadi senjata yang bernilai bagi perusahaan untuk menghadapi peningkatan tantangan dalam industri manufaktur (Hunt, 1989; Noori, 1990 dikutip dalam Lagace dan Bourgault, 2003: 707). Hasil penelitian Youseff (1993) dalam Lagace dan Bourgault (2003) mengenai teknologi berbasis komputer dan pengaruhnya terhadap kinerja menunjukkan bahwa teknologi ini berhasil mengeliminasi aktivitas yang tidak memberikan nilai tambah dan kelompok organisasi yang menerapkan teknologi memiliki fleksibilitas tinggi dibandingkan dengan kelompok yang tidak menerapkan teknologi. Oleh karena itu sangat penting bagi perusahaan untuk mengintegrasikan adopsi teknologi baik program dan praktik-praktik perbaikan produksi maupun aplikasi teknologi baru dengan strategi manufaktur perusahaan (Lagace dan Bourgault, 2003: 709). 
Pendapat serupa dikemukakan oleh Sim (2001) dalam Lagace dan Bourgault (2003) yang menguji dampak TQM, JIT, AMT terhadap kinerja perusahaan. Menurutnya teknik perbaikan (soft technology) perlu diintegrasikan dengan hard technology untuk menghilangkan aktivitas yang tidak memberikan nilai tambah. Melalui aplikasi teknologi baik hard technology maupun soft technology dapat meningkatkan kemampuan perusahaan dalam merespon konsumen, meningkatkan fleksibilitas perusahaan, dan perbaikan respon time pada semua proses produksi dari desain hingga pemberian layanan pada konsumen. Hal ini dapat dicapai dengan meningkatkan metode pengembangan produk, penurunan set up time, memperbaiki cara produksi, dan memperbaiki hubungan dengan pemasok.

Melalui aplikasi teknologi, perusahaan dapat mengeliminasi "sampah" dan mengurangi aktivitas yang tidak menghasilkan nilai tambah yang cenderung menjadi beban biaya produksi pada setiap aktivitas produksi. Aktivitas-aktivitas ini dapat diturunkan melalui tinjauan ekstensif dalam desain pekerjaan, termasuk implementasi sistem pemeliharaan dan manajemen kualitas. Selain itu melalui aplikasi teknologi, proses fleksibel memungkinkan perusahaan untuk menawarkan range produk dan melakukan peningkatan efisiensi (Lagace dan Bourgault, 2003: 707).

Penelitian ini dilakukan pada perusahaan manufaktur skala besar di Indonesia. Model penelitian dengan kerangka kontingensi dikembangkan berdasarkan literatur konseptual dan empiris yang dikemukakan oleh beberapa peneliti (Skiner, 1974; Hitt dan Palla, 1982, Sulaiman et al., 2003). Penelitian ini bertujuan untuk untuk menganalisa apakah adopsi teknologi memoderasi hubungan antara strategi manufaktur dan kinerja operasional perusahaan manufaktur di Indonesia.

\section{TINJAUAN LITERATUR DAN PENGEMBANGAN HIPOTESIS}

\subsection{Dimensi-Dimensi Strategi Manufaktur}

Krawjesky dan Ritzman (2002) mendefinisikan strategi manufaktur sebagai dimensi yang harus dimiliki oleh sistem produksi suatu perusahaan untuk mendukung permintaan pasar dimana perusahaan bersaing. Swamidas dan Newell (1987) mengemukakan bahwa strategi manufaktur dipandang sebagai kekuatan manufaktur yang efektif sebagai satu senjata kompetitif untuk mencapai tujuan bisnis dan perusahaan. Strategi manufaktur mempengaruhi tujuan dan strategi bisnis dan memungkinkan fungsi-fungsi manufaktur untuk memberikan kontribusi dalam meningkatkan daya saing perusahaan dalam jangka panjang (Wheelright dan Hayes, 1985).

Tema umum dalam riset strategi manufaktur adalah mendeskripsikan pilihan perusahaan tentang penekanan kapabilitas atau prioritas kompetitif perusahaan. Menurut beberapa peneliti, strategi manufaktur mewakili prioritas kompetitif (Leong et al., 1990; Burgess et al., 1998). Prioritas kompetitif ini meliputi biaya (cost), kualitas (quality), fleksibilitas (flexibility), dan pengiriman (delivery). Stonebraker dan Leong (1994), seperti dikutip dalam Badri et al. (2000) mendefinisikan strategi biaya sebagai produksi dan distribusi produk dengan biaya terendah dan sumber daya tersisa (waste resource) yang minimum. Strategi kualitas didefinisikan sebagai aktivitas perusahaan untuk memproduksi produk yang sesuai dengan spesifikasi atau memenuhi kebutuhan konsumen. Strategi pengiriman didefinisikan sebagai keandalan dalam memenuhi jadwal pengiriman yang diminta dan di dijanjikan, atau kecepatan dalam merespon pemesanan konsumen. Sedangkan strategi fleksibilitas didefinisikan sebagai kemampuan untuk merespon perubahan cepat dalam produk, jasa, dan proses.

Harga yang lebih rendah dapat meningkatkan permintaan produk atau jasa tapi juga mengurangi profit margin jika produk atau jasa tidak dapat diproduksi pada harga yang lebih rendah. Untuk dapat bersaing dalam lingkungan bisnis dengan berbasis pada biaya, seorang manajer manufaktur perlu menawarkan produk dan jasa pada biaya per unit yang rendah baik biaya tenaga kerja, material, scrap, maupun biaya overhead lainnya. Strategi kualitas memfokuskan pada pentingnya memproduksi produk dan jasa yang dapat memuaskan spesifikasi 
dan kebutuhan konsumen. Oleh karenanya, perusahaan perlu memperhatikan masalah perbaikan kualitas sehingga dapat mengurangi biaya produksi dengan melakukan sesuatu dengan benar saat pertama kali barang dan jasa diproduksi dapat mengeliminasi "waste." Perbaikan kualitas merupakan salah satu cara bagi organisasi untuk memperbaiki kinerja bisnis (Ward et al., 1995).

Strategi fleksibilitas merupakan kemampuan untuk merespon perubahan cepat baik perubahan produk, jasa, maupun proses. Fleksibilitas manufaktur didefinisikan sebagai kemampuan perusahaan manufaktur untuk mengalokasikan dan mengalokasikan kembali sumber daya yang dimiliki secara efektif dalam merespon perubahan lingkungan dan kondisi internal (Gerwin, 1993). Sedangkan Braglia dan Petroni (2000) menyatakan bahwa fleksibilitas mencakup mesin, proses, produk, volume, dan lay out. Strategi pengiriman meliputi kemampuan dalam merespon pemesanan konsumen. Leong et al. (1990) mendefinisikan strategi pengiriman sebagai kemampuan pengiriman (dengan memenuhi jadwal pengiriman maupun janji pengiriman) dan kecepatan pengiriman (bertindak cepat atas pemesanan konsumen). Pengukuran kinerja pengiriman menekankan pada aktifitas yang memfokuskan pada peningkatan reliabilitas pengiriman misalnya pengiriman yang tepat waktu, akurasi dalam status persediaan, dan waktu tunggu pengiriman.

\subsection{Adopsi Teknologi: Hard Technology dan Soft Technology}

Teknologi didefinisikan sebagai kemampuan mengenali masalah-masalah teknis dan mengeksploitasi konsep-konsep untuk memecahkan masalah teknis yang ada. Teknologi merupakan peralatan atau perangkat seperti equipment, software, dan hardware, yang digunakan untuk memecahkan masalah operasional secara efektif dalam suatu organisasi (Autioe dan Leimanen, 1995). Teknologi pada industri manufaktur mencakup hard technology dan soft technology. Hard technology seperti Advanced Manufacturing Technology (AMT) dan Computerbased technology telah semakin banyak diadopsi oleh industri menufaktur saat ini (Schroeder dan Sohal, 1999; Butcher, et al., 1999).

Dalam menghadapi kompetisi, perusahaan manufaktur dituntut untuk mengambil dua tindakan penting yaitu, pertama, mengadopsi satu atau lebih hard technology seperti CAD (Computer Aided Design), CAM (Computer Aided Manufacturing), CNC (Computer Numerical Control), Robotics, FMS (Flexible Manufacturing System), dan CIM (Computer Integrated Manufacturing). CAM merupakan sistem komputerisasi untuk mengontrol langsung mesin dan peralatan dalam proses pemanufakturan, sedangkan CAD merupakan sistem elektronik untuk mendesain produk baru atau mengubah produk yang ada. Untuk mensukseskan adopsi CAD dan CAM, manajer perlu menyesuaikan kapabilitas perusahaan dalam desain, manufaktur, dan fungsifungsi lain (Aggarwal, 1995).

CNC digunakan untuk mengontrol operasi peralatan mesin, sehingga melalui aplikasi CNC akan mengeliminasi operator. Peralatan mesin ini mendukung aplikasi CAM dalam perusahaan. CNC merupakan bagian peralatan mesin yang masing-masing dikontrol oleh microcomputer (Aggarwal, 1995). FMS merupakan penggunaan sistem komputer untuk mengontrol penanganan material pada masing-masing produksi (Heizer dan Render, 2004), sedangkan CIM merupakan filosofi organisasi dan manajemen yang terintegrasi dengan bantuan sistem komputer. Dengan kata lain, CIM mencakup integrasi desain produk, perencanaan proses, dan pemanufakturan dalam sistem komputer. Sedangkan Robotics yaitu penggunaan flexible machine dengan kemampuan menangani dan memindahkan untuk menggantikan kerja manusia.

Kedua, memilih satu atau lebih soft technology yang ada yaitu diantaranya JIT (Just In Time), TQM (Total Quality Management), MRP (Material Requirement Planning), dan TPM (Total Productive Manintanance). TQM adalah optimasi kinerja pada semua bagian dan fungsi operasi, prosedur, sistem, pengendalian, struktur, dan kultur organisasi (Warnock, 1996). TQM merupakan program perbaikan terus menerus yang dilakukan secara bertahap dan tidak pernah berakhir (Sohal dan Terziovsky, 2000). 
JIT merupakan seperangkat metode atau teknik yang diaplikasikan pada sistem pembelian, fungsi pabrikasi dan fungsi pengiriman. Filosofi JIT yaitu mengeliminasi semua aktivitas yang tidak penting dan tidak memberikan nilai tambah di manapun aktivitas itu berada (Yasin dan Wafa, 1997). MRP merupakan teknik permintaan dependen yang menggunakan bill of material, persediaan, expected received, dan MPS (master production schedule) untuk menentukan kebutuhan material (Heizer dan Render, 2004). Sedangkan TPM adalah pendekatan inovatif untuk perawatan peralatan (hardware atau software) dan mesin pabrik. Implemetasi TPM memberikan kontribusi dalam mengurangi work in progress, meningkatkan kualitas produk, mengurangi waktu siklus produksi, dan sangat efektif untuk optimasi mesin dan peralatan (Tsang dan Chan, 2000).

\subsection{Kinerja Manufaktur Perusahaan}

Literatur menyarankan bahwa dalam kebanyakan situasi, ukuran kinerja perusahaan yang paling sering digunakan adalah ukuran finansial (Nash, 1984). Profit margin, return on asset $(R O A)$, return on equity (ROE), return on sales (ROS), merupakan ukuran kinerja financial yang sering digunakan (Galbraight and Scendell, 1983). Ketepatan ukuran kinerja yang digunakan dalam suatu penelitian tergantung pada situasi dan keunikan kondisi dalam suatu studi. Sangat sulit untuk menetapkan ukuran tunggal kesuksesan bisnis. Oleh karena itu, keterkaitan antara manufaktur dengan semua ukuran yang tersedia dan diterima secara umum perlu dianalisa (Demeter, 2003). Dalam penelitian ini kinerja operasional diukur melalui biaya produk per unit, kualitas proses, kualitas produk, kemampuan menangani perubahan jumlah permintaan, kemampuan memenuhi perubahan selera pelanggan, pengiriman tepat pada waktunya, kemampuan pengiriman sebelum waktu yang ditentukan (Leong et al., 1990).

\subsection{Hubungan Strategi Manufaktur Dan Teknologi}

Literatur konseptual maupun empiris yang membahas tentang hubungan antara strategi manufaktur dan teknologi telah ada sejak lama. Skinner (1974) seperti dikutip dalam Ellitan et al. (2003), mengemukakan variasi prioritas strategik termasuk biaya, kualitas produk, reliabilitas pengiriman, fleksibilitas dalam memproduksi produk baru secara cepat dan fleksibilitas untuk merespon perubahan volume yang dapat dicapai dengan menggunakan teknologi manufaktur (manufacturing technology).

Miller (1994), seperti dikutip dalam Ellitan et al. (2003), mengemukakan pentingnya link antara manajemen teknologi dan pilihan strategi manufaktur untuk mencapai superior performance. Teknologi berperan untuk menciptakan desain yang bagus untuk memenuhi kriteria desain yang tepat yang dispesifikasi oleh manufacturing task (yaitu spesifikasi tujuan yang harus dicapai oleh fungsi-fungsi manufaktur). Boyer dan Pegell (2000) dalam Ellitan (2003) mengemukakan bahwa efektifitas strategi operasi perusahaan dapat diukur dengan menilai keterkaitan atau konsistensi antara prioritas kompetitif yang menekankan dan merespon perubahan lingkungan berdasarkan struktur dan infrastruktur operasi. Tingkat kesesuaian antara prioritas kompetitif dan keputusan yang terkait dengan struktural dan investasi infrastruktural memberikan kunci untuk mengembangkan strategi operasi sebagai senjata kompetitif. Barnejee (2000) dalam Ellitan (2003) mengemukakan bahwa tujuan utama arsitektur strategi adalah memberikan pedoman bagi strategi fungsional untuk mengembangkan road map terkait dengan identifikasi kompetensi inti dan teknologi yang memuaskan kebutuhan bisnis.

Beberapa studi empiris yang mengkaji tentang adanya hubungan strategi manufaktur dan teknologi juga telah dilakukan beberapa peneliti (Gordon dan Sohal, 2000). Burgess et al. (1998) mengeksplorasi aspek-aspek kunci perusahaan yang mencakup prioritas kompetitif (strategi manufaktur), proses inovasi (adopsi teknologi), dan kinerja perusahaan. Prioritas kompetitif mengindikasikan area mana dari process performance yang harus ditekankan untuk mencapai kinerja yang sukses. Cagliano dan Spina (2000) dalam Ellitan (2003) mengeksplorasi basis empiris dari strategic alignment pilihan strategi manufaktur yang merupakan prioritas kompetitif perusahaan dan pengalaman perusahaan dalam menentukan pilihan program perbaikan. Tujuan 
manufaktur dapat tercapai jika program perbaikan (sekelompok keputusan struktural dan infrastruktural yang diturunkan dari pengalaman beberapa leading companies yang telah dibuktikan kesuksesannya) didasarkan pada prioritas kompetitif (strategi manufaktur).

Chase (2001) dalam Ellitan (2003) mengemukakan beberapa alasan mengadopsi teknologi untuk mencapai tujuan perusahaan terkait dengan prioritas kompetitif, yaitu: biaya (cost), perusahaan pada umumnya bertujuan untuk mengurangi biaya produk/jasa yang memungkinkan perusahaan untuk membuat profit lebih besar dan mencapai harga lebih rendah untuk meningkatkan volume penjualan. Aplikasi teknologi dalam perusahan dapat menurunkan biaya dengan cara menurunkan biaya material, tenaga kerja, biaya distribusi, misalnya, melalui aplikasi teknologi waktu yang diperlukan tenaga kerja untuk memproduksi suatu produk dapat diturunkan sehingga biaya tenaga kerja dapat dikurangi. Kualitas (Quality), aplikasi teknologi bermanfaat bagi perusahaan untuk meningkatkan kualitas produk, dan meningkatkan volume successive innovation dengan cara meminimalkan tingkat kerusakan produk dan mengeliminasi sumber daya terbuang (waste recources). Fleksibilitas (Flexibility), aplikasi teknologi bermanfaat untuk meningkatkan variasi produk dan pencapaian extensive customization, untuk memperoleh peningkatan pangsa pasar dalam lingkungan kompetitif, perusahaan harus lebih fleksibel dalam operasi dan memuaskan segmen pasar, sehingga aplikasi teknologi sangat diperlukan untuk mendukung pencapaian tujuan fleksibilitas perusahaan. Pengiriman (Delivery), teknologi mendukung terciptanya kecepatan pengiriman yang diukur melalui lead time (waktu tunggu) yang diperlukan. Aplikasi EDI (electronic data interchange) dan mesin fax secara otomatis dapat menurunkan waktu yang diperlukan untuk mengirimkan informasi dari satu lokasi ke lokasi yang lain, dan menurunkan waktu tunggu untuk pelayanan maupun operasi.

Sulaiman et al. (2003: 266) mengemukakan teknologi merupakan sumber keunggulan kompetitif perusahaan. Untuk meraih keunggulan kompetitif, perusahaan perlu menyelaraskan teknologi dengan strategi perusahaan. Teknologi diperlakukan sebagai variabel pemoderasi antara hubungan strategi bisnis dan kinerja. Hasil penelitian menunjukkan bahwa teknologi dan lingkungan bisnis memoderasi hubungan strategi bisnis dengan kinerja perusahaan. Beberapa studi terdahulu membuktikan pentingnya strategi manufaktur dalam peningkatan kinerja (Demeter, 2003). Penelitian tersebut memasukkan hubungan antara kinerja dengan teknologi manufaktur melalui implementasinya dalam praktek manajemen kualitas (Beaumont dan Schroder, 1997; serta Das dan Narasimhan, 2001).

Penelitian ini menguji pentingnya peran adopsi teknologi sebagai pemoderasi hubungan strategi manufaktur dan kinerja perusahaan. Model konseptual strategi manufaktur dan pengaruh variabel pemoderasi, adopsi teknologi, terhadap kinerja operasional digambarkan dalam Gambar 1. Hipotesis yang akan diuji meliputi:

Hipotesis 1: Adopsi teknologi (hard technology) memoderasi hubungan antara pilihan strategi manufaktur dan kinerja perusahaan

Hipotesis 2: Adopsi teknologi (soft technology) memoderasi hubungan antara pilihan strategi manufaktur dan kinerja perusahaan 


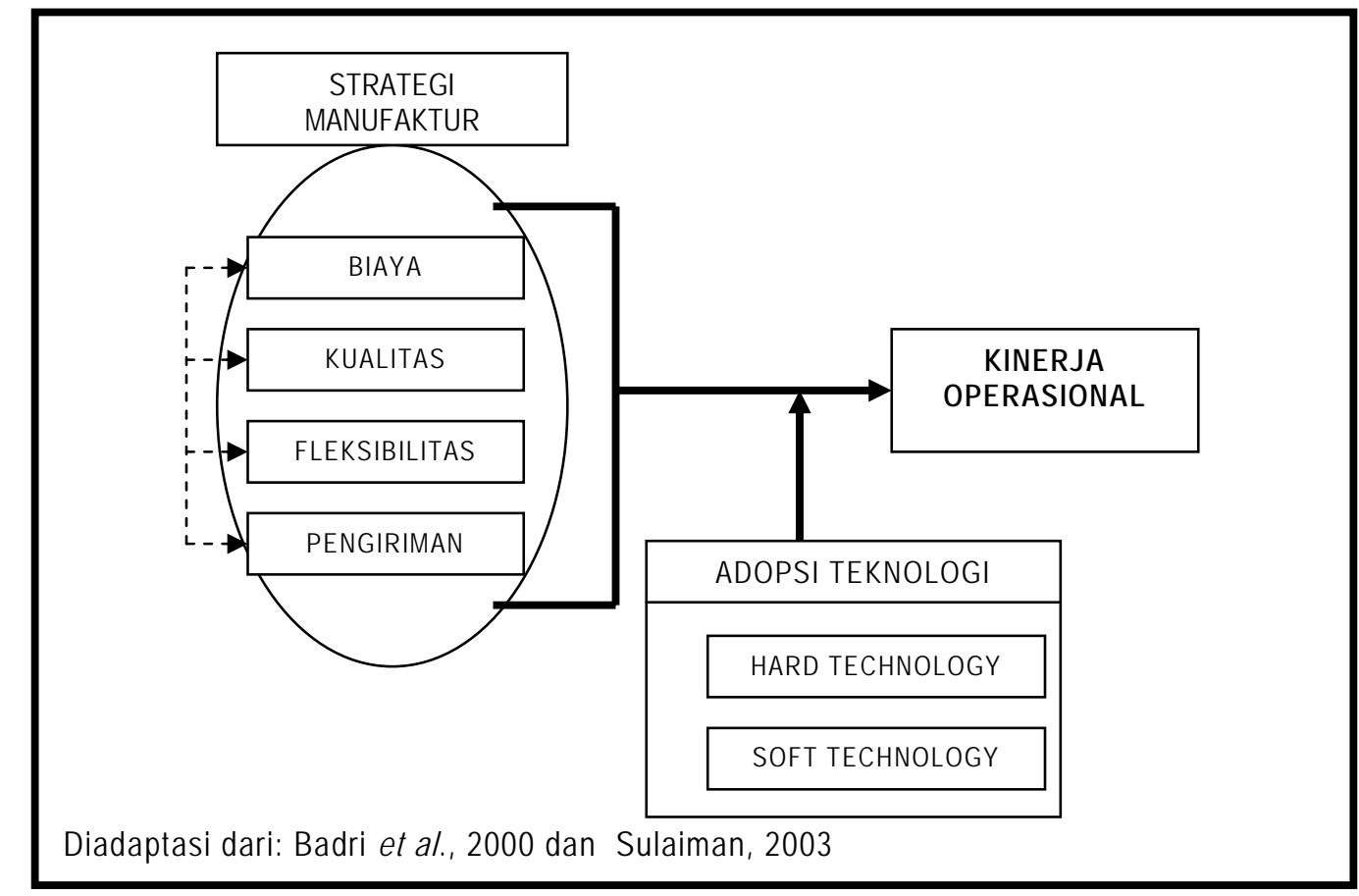

\section{Gambar 1 \\ Model Penelitian}

\section{METODA PENELITIAN}

Data penelitian diperoleh melalui penyebaran kuesioner dan direct survey yang ditujukan kepada pimpinan perusahaan. Sampel diambil secara random dari perusahaan manufaktur yang terdaftar di Direktori Perusahaan Manufaktur yang diterbitkan oleh Biro Pusat Statistik, tahun 2003. Penggolongan atau klasifikasi industri yang digunakan dalam penelitian ini adalah klasifikasi berdasarkan data Statistik Industri Besar dan Sedang yang diterbitkan oleh Biro Pusat Statistik, tahun 2003. Klasifikasi Industri berdasarkan International Standart Industrial Classification (ISIC) yang telah disesuaikan dengan kondisi di Indonesia dengan nama Klasifikasi Lapangan Usaha Industri/KLUI (BPS, 2003). Penggolongan skala perusahaan dibagi dalam empat golongan yaitu 1) besar, dengan jumlah tenaga kerja 100 orang atau lebih, 2) sedang, dengan jumlah tenaga kerja 20-99 orang, 3) kecil, dengan jumlah tenaga kerja 5-19 orang, dan 4) rumah tangga, dengan jumlah tenaga kerja 1-4 orang.

Dari 525 kuesioner (95, 45\%), 9 responden tidak bersedia berpartisipasi, 21 kuesioner kembali (pindah alamat atau tutup). Total kuesioner yang kembali 92 kuesioner dan 5 diantaranya tidak diisi secara lengkap sehingga tidak dapat digunakan dalam analisis data. Teknik pengumpulan data juga dilakukan dengan cara mendatangi pimpinan perusahaan secara langsung dan memohon kesediaan mereka untuk menjadi responden dalam penelitian ini. Dari 25 kuesioner $(4,54 \%)$ yang dititipkan pada perusahaan-perusahaan tersebut, hanya 29 kuesioner yang dikembalikan. Secara lengkap sampel dan tingkat pengembalian kuesioner dalam penelitian ini disajikan dalam Tabel 1. 
Tabel 1

Sampel dan Tingkat Pengembalian

\begin{tabular}{lr}
\hline Total kuesioner yang dikirimkan & 550 \\
Perusahaan tutup/pindah alamat & 21 \\
Perusahaan menolak berpartisipasi & 9 \\
Total Kuesioner kembali & 111 \\
Tingkat pengembalian & $111 / 550 \times 100 \%=20,18 \%$ \\
Tingkat pengembalian berdasarkan kuesioner yang & $106 / 550 \times 100 \%=19,27 \%$ \\
diolah & \\
\hline
\end{tabular}

Sumber: Data Diolah

\subsection{Pengujian Respon Bias}

Data penelitian diperoleh dari dua sumber yaitu mail survey dan beberapa responden didatangi langsung sehingga perlu dilakukan pengujian respon bias. Uji respon bias dilakukan untuk melihat apakah ada perbedaan karakteristik antara jawaban responden yang diperoleh melalui mail survey dan jawaban responden yang diperoleh dengan didatangi langsung. Untuk menguji adanya respon bias digunakan uji beda t-test untuk menentukan apakah dua sampel yang tidak berhubungan memiliki rata-rata berbeda. Kesimpulan diambil berdasarkan nilai signifikansi masing-masing variabel lebih dari 0.05 (sign > 0.05). Hasil pengujian respon bias terhadap masing-masing variabel dirangkum dalam Tabel 2. Berdasarkan hasil pengujian $t$ test dapat disimpulkan tidak ada perbedaan karakteristik jawaban responden yang signifikan antara jawaban responden yang didapat melalui mail survey dan responden yang didatangi langsung. Dengan demikian pengolahan data untuk analisis selanjutnya bisa digabungkan antara kuesioner yang diperoleh melalui mail survey dan didatangi langsung.

Tabel 2

Pengujian Response Bias

\begin{tabular}{cccccl}
\hline Variabel & \multicolumn{2}{c}{ Lavene's test } & \multicolumn{2}{c}{ t test } & Keterangan \\
\cline { 2 - 5 } & $\mathbf{F}$ & Sign & $\mathbf{t}$ & Sign & \\
C & 6.400 & 0.013 & 1.402 & 0.174 & Tidak Signifikan \\
Q & 3.141 & 0.079 & 0.266 & 0.791 & Tidak Signifikan \\
F & 1.978 & 0.163 & 0.446 & 0.656 & Tidak Signifikan \\
D & 0.041 & 0.840 & 0.766 & 0.445 & Tidak Signifikan \\
HTECH & 0.014 & 0.905 & -1.431 & 0.155 & Tidak Signifikan \\
STECH & 1.648 & 0.202 & -1.728 & 0.087 & Tidak Signifikan \\
KOp & 0.893 & 0.347 & -0.914 & 0.363 & Tidak Signifikan \\
\hline
\end{tabular}

Sumber : Data Diolah

\subsection{Pengukuran Variabel}

Variabel-variabel yang digunakan dalam penelitian serta pengukurannya dijabarkan pada bagian berikut. Variabel bebas, dalam penelitian ini adalah pilihan strategi manufaktur yang meliputi empat prioritas kompetitif. Strategi manufaktur meliputi item-item pertanyaan yang terkait dengan biaya bisnis, kualitas, fleksibilitas, dan pengiriman. Skala likert 5 point digunakan untuk 
mengukur tingkat perhatian perusahaan terhadap pentingnya strategi manufaktur ( $1=$ sangat tidak penting, dan $5=$ sangat penting). Variabel Moderator, dalam penelitian ini meliputi adopsi hard technology dan soft technology. Adopsi hard technology meliputi CAD, CAM, CNC, FMS, CIM, dan Robotics. Sedangkan adopsi soft technology meliputi adopsi TQM, JIT, MRP, dan TPM. Skala likert 5 point digunakan untuk mengukur tingkat adopsi teknologi (1=tidak mengadopsi, dan 5= sangat tinggi). Variabel terikat dalam penelitian ini adalah kinerja operasional yang diukur dari segi produktifitas, biaya, kualitas, fleksibilitas, dan kemampuan pengiriman. Skala likert 5 point digunakan untuk mengukur kinerja operasional dibandingkan dengan rata-rata industri dimana perusahaan beroperasi ( 1 = sangat tidak penting, dan $5=$ sangat penting).

\section{HASIL ANALISIS DAN PEMBAHASAN}

\subsection{Profil Responden}

Dari 106 perusahaan yang telah berpartisipasi dalam studi ini, semuanya adalah perusahaan manufaktur berskala besar, menurut kriteria yang digunakan dalam penelitian ini, yaitu berdasarkan jumlah tenaga kerja yang dimiliki masing-masing perusahaan. Profil perusahaan yang berpartisipasi dalam penelitian ini adalah dilihat dari segi bidang usaha, lama perusahaan beroperasi, jumlah tenaga kerja tetap, aset yang dimiliki, dan kinerja secara umum yang dicapai selama tiga tahun terakhir. Perusahaan ini bergerak dalam bidang usaha yang berbeda-beda. 
Tabel 3

Profil Responden

\begin{tabular}{|c|c|c|c|}
\hline Dimensi & Kategori & $\begin{array}{l}\text { Jumlah } \\
\text { responden }\end{array}$ & Persentase \\
\hline \multirow[t]{4}{*}{ Umur perusahaan } & 5-10 tahun & 17 & 16.04 \\
\hline & $>10-20$ tahun & 38 & 35.85 \\
\hline & $>20-30$ tahun & 32 & 30.19 \\
\hline & Lebih dari 30 tahun & 19 & 17.92 \\
\hline \multirow[t]{6}{*}{ Bidang Usaha } & Makanan, minuman, dan tembakau. & 7 & 6.60 \\
\hline & Tekstil, pakaian, kulit. & 14 & 13.21 \\
\hline & $\begin{array}{l}\text { Kayu, bamboo, rotan, kerajinan, } \\
\text { perabot. }\end{array}$ & & 12.26 \\
\hline & $\begin{array}{l}\text { Industri kimia, minyak, batubara, } \\
\text { karet, dan plastik. }\end{array}$ & & 22.64 \\
\hline & $\begin{array}{l}\text { Barang bukan logam, mineral, } \\
\text { kecuali batu bara. }\end{array}$ & 14 & 13.21 \\
\hline & $\begin{array}{l}\text { Barang logam, permesinan, otomotif, } \\
\text { electronic, dan komputer. }\end{array}$ & 34 & 32.08 \\
\hline \multirow[t]{3}{*}{ Pemilik } & Lokal & 84 & 79.24 \\
\hline & Asing & 17 & 16.04 \\
\hline & Joint venture & 5 & 4.72 \\
\hline \multirow[t]{6}{*}{ Kerjasama } & Tidak ada kerjasama & 43 & 40.57 \\
\hline & Japan & 29 & 27.36 \\
\hline & Hongkong, Taiwan, Korea & 12 & 11.32 \\
\hline & ASEAN & 3 & 2.83 \\
\hline & USA, UK, Australia & 11 & 10.38 \\
\hline & Lain-lain & 8 & 7.54 \\
\hline \multirow{4}{*}{ Tenaga kerja } & 100 - 999 tenaga kerja. & 21 & 19.81 \\
\hline & 1000 - 1999 tenaga kerja & 10 & 9.43 \\
\hline & 2000 - 2999 tenaga kerja & 17 & 16.04 \\
\hline & 3000 atau lebih tenaga kerja & 58 & 54.72 \\
\hline Kinerja secara & Meningkat > 15\% & 14 & 13.21 \\
\hline umum selama & Menurun <15\% & 16 & 15.09 \\
\hline tiga tahun ter- & Tidak ada perubahan & 18 & 16.98 \\
\hline \multirow[t]{2}{*}{ akhir } & Meningkat < 15\% & 47 & 44.34 \\
\hline & Meningkat > 15\% & 11 & 10.38 \\
\hline \multirow[t]{5}{*}{ Asset } & Kurang dari 25 milyar rupiah & 3 & 2.83 \\
\hline & 25-100 milyar Rupiah. & 32 & 30.19 \\
\hline & > 100 -500 milyar Rupiah. & 41 & 38.68 \\
\hline & > 500 - 1000 milyar Rupiah. & 14 & 13.21 \\
\hline & Lebih dari 1 Trilyun Rupiah. & 16 & 15.09 \\
\hline
\end{tabular}

Sumber: Data diolah 
Berdasarkan data dalam Tabel 3, sebagian besar perusahaan yang berpartisipasi dalam penelitian ini telah beroperasi selama 10-20 tahun (35.85\%). Berdasarkan bidang usaha sebagian besar perusahaan bergerak dalam bidang otomotif, permesinan, elektronik, barang logam, dan komputer (32.08\%). Sebagian besar perusahaan merupakan milik pengusaha lokal (79.24\%), berdasarkan jumlah tenaga kerja sebagian besar perusahaan memiliki tenaga kerja diatas 3000 orang (54.72\%), dan berdasarkan aset yang dimiliki sebagian besar perusahaan memiliki asset sebesar 100-500 milyar Rupiah (38.68\%).

\subsection{Pengujian Validitas Dan Reliabilitas}

Suatu alat ukur atau instrumen pengukuran dikatakan baik jika memenuhi kriteria validitas, reliabilitas, dan kepraktisan. Validitas menunjukkan sejauh mana alat ukur yang digunakan benarbenar dapat mengukur obyek yang ingin diukur dalam penelitian. Reliabilitas menunjukkan sejauh mana instrumen pengukuran yang digunakan bebas dari kesalahan acak atau tidak stabil.

Pengujian reliabilitas instrumen tetap dilakukan dengan menghitung Cronbach's alpha. Instrumen dianggap mempunya reliabilitas yang tinggi apabila nilai Cronbach's alpha lebih tinggi dari 0,5 (Ghozali, 2002). Tabel 4 menyajikan rangkuman uji reliabilitas dan validitas instrumen. Hasil studi ini menunjukkan reliabilitas instrument yang tinggi. Cronbach's alpha untuk variabel strategi manufaktur nilai Cronbach alpha berkisar antara 0.825-0.896, untuk variabel adopsi teknologi sebesar 0.897 (hard technology) dan 0.858 (soft technology), dan untuk variabel kinerja operasional sebesar 0.836 .

Pengujian validitas dilakukan dengan menggunakan analisis faktor (factor analysis) dengan varimax rotation. Factor loadings 0.55 sudah dapat dikatakan memenuhi standar minimal untuk ukuran sampel sejumlah minimal 100 (Hair et al., 1998). Pada Tabel 4 terlihat bahwa nilai factor loadings untuk masing-masing dimensi dalam variabel lingkungan dan strategi manufaktur semuanya lebih dari 0.55

Tabel 4

Pengujian Validitas

\begin{tabular}{clcc}
\hline Variabel & \multicolumn{1}{c}{ Dimensi } & $\begin{array}{c}\text { Loading } \\
\text { Factor }\end{array}$ & $\begin{array}{c}\text { Cronbach's } \\
\text { Alpha }\end{array}$ \\
\hline Strategi Manufaktur & Biaya Rendah (C) & $0.770-0.868$ & 0.849 \\
& Kualitas (Q) & $0.550-0.801$ & 0.825 \\
& Fleksibilitas (F) & $0.603-0.847$ & 0.858 \\
& Pengiriman (D) & $0.765-0.862$ & 0.896 \\
Adopsi Teknologi & Hard Technology & $0.678-0.852$ & 0.897 \\
& Soft Technology & $0.670-0.882$ & 0.858 \\
Kinerja Perusahaan & & $0.629-0.899$ & 0.836 \\
\hline
\end{tabular}

Sumber: Data Diolah

\section{3. Pengujian Hipotesis}

\section{3. 1. Efek Pemoderasian Hard Technology terhadap Hubungan Strategi Manufaktur dan Kinerja Operasional}

Pengujian Hipotesis satu dilakukan untuk memberikan bukti empiris adanya pengaruh pemoderasian hard technology terhadap hubungan antara strategi manufaktur dan kinerja perusahaan. Pengujian Hipotesis satu dirangkum dalam Tabel 5 . Kolom blok pada Tabel 5 memperlihatkan urutan pemasukan variabel kedalam persamaan untuk pengujian hipotesis peran pemoderasian adopsi hard technology terhadap hubungan strategi manufaktur dan kinerja operasional. Blok satu memperlihatkan bahwa yang pertama dimasukkan adalah variabel-variabel pilihan strategi manufaktur (biaya rendah/C, kualitas/Q, fleksibilitas/F, dan pengiriman/D). Blok ini menunjukkan nilai $\mathrm{R}^{2}$ sebesar 0.023 . 
Tabel 5

Hasil Pengujian Pengaruh Adopsi Hard Technology Terhadap Hubungan Prioritas Kompetitif Kinerja Operasional

\begin{tabular}{|c|c|c|c|c|c|c|c|c|}
\hline & \multirow[t]{2}{*}{ Model } & \multirow{2}{*}{$\begin{array}{c}\text { Standardized } \\
\text { Coeffisien } \\
\text { B }\end{array}$} & \multicolumn{2}{|c|}{ Uji t } & \multirow[t]{2}{*}{$\mathbf{R}^{2}$} & \multirow[t]{2}{*}{$\Delta \mathrm{R}^{2}$} & \multirow[t]{2}{*}{$\Delta \mathrm{F}$} & \multirow[t]{2}{*}{ Sign } \\
\hline & & & $T$ & Sign & & & & \\
\hline \multirow[t]{5}{*}{1} & $\begin{array}{c}\text { (Constan } \\
\text { t) }\end{array}$ & & 4.991 & 0.000 & 0.023 & 0.023 & 0.601 & 0.663 \\
\hline & C & 0.048 & $\begin{array}{c}0.047 \\
6\end{array}$ & 0.635 & & & & \\
\hline & Q & 0.109 & 1.071 & 0.287 & & & & \\
\hline & $F$ & -0.034 & -0.331 & 0.741 & & & & \\
\hline & D & 0.073 & 0.717 & 0.475 & & & & \\
\hline \multirow[t]{6}{*}{2} & $\begin{array}{c}\text { (Constan } \\
\text { t) }\end{array}$ & & 2.918 & 0.004 & 0.243 & 220 & $\begin{array}{c}29.05 \\
9\end{array}$ & 0.000 \\
\hline & C & 0.054 & 0.608 & 0.545 & & & & \\
\hline & Q & 0.056 & 0.623 & 0.535 & & & & \\
\hline & $F$ & 0.036 & 0.392 & 0.696 & & & & \\
\hline & D & 0.053 & 0.590 & 0.556 & & & & \\
\hline & ADT & 0.476 & 5.391 & 0.000 & & & & \\
\hline \multirow[t]{10}{*}{3} & $\begin{array}{c}\text { (Constan } \\
\text { t) }\end{array}$ & & -0.208 & 0.836 & 0.330 & 0.087 & 3.101 & 0.019 \\
\hline & C & -0.163 & -0.391 & 0.697 & & & & \\
\hline & Q & 0.013 & 0.030 & 0.976 & & & & \\
\hline & $\mathrm{F}$ & -0.737 & -1.754 & 0.083 & & & & \\
\hline & D & 1.793 & 3.366 & 0.001 & & & & \\
\hline & ADT & 1.249 & 1.469 & 0.145 & & & & \\
\hline & CAD & 0.359 & 0.541 & 0.590 & & & & \\
\hline & QAD & 0.052 & 0.062 & 0.950 & & & & \\
\hline & FAD & 1.088 & 1.924 & 0.057 & & & & \\
\hline & DAD & -2.662 & -3.310 & 0.001 & & & & \\
\hline
\end{tabular}

Sumber: Data Diolah

Ketika variabel adopsi hard technology (htech) dimasukkan dalam persamaan (Blok 2), nilai $\mathrm{R}^{2}$ meningkat menjadi 0.243 dan $\Delta \mathrm{F}$ sebesar 29.059. Peningkatan tersebut adalah signifikan dengan nilai signifikansi $0.000<0.05$ (sig 5\%). Ini menunjukkan bahwa sebesar $24.3 \%$ variasi variabel kinerja operasional dapat dijelaskan oleh variabel strategi manufaktur dan adopsi teknologi (hard technology) sedangkan $75.7 \%$ dijelaskan oleh faktor lain.

Pada tahap selanjutnya (Blok 3) ketika variabel interaksi dimasukkan kedalam persamaan, nilai $\mathrm{R}^{2}$ meningkat 0.87 dari blok 2 sehingga menjadi 0.330 dan $\Delta \mathrm{F}=3.101$. Peningkatan tersebut signifikan karena nilai signifikansi sebesar 0.019 lebih kecil dari 5\% (sign < 5\%). Berdasarkan kriteria MRA, maka variabel adopsi hard technology merupakan quase moderator. Baik sebagai variabel bebas maupun variabel pemoderasi adopsi hard technology (htech) secara signifikan mempengaruhi kinerja operasional (KOp) sebagai variabel terikat. Dengan demikian dapat 
disimpulkan bahwa hipotesis 2 yang menyatakan variabel adopsi hard technology memoderasi hubungan antara pilihan strategi manufaktur dengan kinerja operasional perusahaan terbukti.

\section{5 .3. 2. Efek Pemoderasian Soft Technology terhadap Hubungan Strategi Manufaktur dan Kinerja Operasional \\ Pengujian Hipotesis dua dilakukan untuk memberikan bukti empiris adanya pengaruh} pemoderasian soft technology terhadap hubungan antara strategi manufaktur dan kinerja perusahaan. Pengujian Hipotesis dua dirangkum dalam Tabel 6. Blok 1 menunjukkan nilai $\mathrm{R}^{2}$ sebesar 0.023. Pada (Blok 2), nilai $\mathrm{R}^{2}$ meningkat menjadi 0.133 dan $\Delta \mathrm{F}$ sebesar 12.724 . Peningkatan tersebut signifikan dengan nilai signifikansi $0.001<0.05$ (sig 5\%). Ini menunjukkan bahwa sebesar $13.3 \%$ variasi variabel kinerja operasional dapat dijelaskan oleh variabel strategi manufaktur dan adopsi teknologi (soft technology), sedangkan 86.7\% dijelaskan oleh faktor lain. Blok 3 ketika variabel interaksi dimasukkan kedalam persamaan, nilai $\mathrm{R}^{2}$ meningkat 0.009 dari blok 2 sehingga menjadi 0.143 dan $\Delta \mathrm{F}=0.260$. Peningkatan tersebut tidak signifikan karena nilai signifikansi sebesar 0.903 lebih besar dari $5 \%$ (sign > 5\%).

Berdasarkan kriteria MRA, maka variabel adopsi soft technology bukan merupakan variabel moderator, melainkan variabel independent predictor terhadap kinerja operasional perusahaan. Pengujian ini membuktikan bahwa soft technology memoderasi hubungan antara pilihan strategi manufaktur dan kinerja operasional tidak terbukti, atau dengan perkataan lain variabel soft technology berpengaruh terhadap kinerja operasional tetapi bukan merupakan variabel yang memperkuat atau memperlemah kinerja operasional. 
Tabel 6

Hasil Pengujian Pengaruh Adopsi Soft Technology Terhadap Hubungan Prioritas Kompetitif Kinerja Operasional

\begin{tabular}{|c|c|c|c|c|c|c|c|c|}
\hline & \multirow[t]{2}{*}{ Model } & \multirow{2}{*}{$\begin{array}{c}\text { Standardized } \\
\text { Coeffisien } \\
\text { B }\end{array}$} & \multicolumn{2}{|c|}{ Uji t } & \multirow[t]{2}{*}{$\mathrm{R}^{2}$} & \multirow[t]{2}{*}{$\Delta \mathrm{R}^{2}$} & \multirow[t]{2}{*}{$\Delta \mathrm{F}$} & \multirow[t]{2}{*}{ Sign } \\
\hline & & & $T$ & Sign & & & & \\
\hline \multirow[t]{5}{*}{1} & (Constant) & & 4.991 & 0.000 & 0.023 & 0.023 & 0.601 & 0.663 \\
\hline & $\mathrm{C}$ & 0.048 & 0.0476 & 0.635 & & & & \\
\hline & $\mathrm{Q}$ & 0.109 & 1.071 & 0.287 & & & & \\
\hline & $\mathrm{F}$ & -0.034 & -0.331 & 0.741 & & & & \\
\hline & $D$ & 0.073 & 0.717 & 0.475 & & & & \\
\hline \multirow[t]{6}{*}{2} & (Constant) & & 3.561 & 0.001 & 0.133 & 0.110 & 12.724 & 0.001 \\
\hline & $C$ & 0.052 & 0.543 & 0.589 & & & & \\
\hline & $\mathrm{Q}$ & 0.059 & 0.610 & 0.543 & & & & \\
\hline & $F$ & 0.003 & 0.033 & 0.973 & & & & \\
\hline & D & 0.079 & 0.823 & 0.413 & 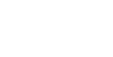 & & & \\
\hline & ADT & -0.337 & 3.567 & 0.001 & & & & \\
\hline \multirow[t]{10}{*}{3} & (Constant) & & 0.579 & 0.564 & 0.143 & 0.009 & 0.260 & 0.903 \\
\hline & $C$ & -0.219 & -0.422 & 0.674 & & & & \\
\hline & $\mathrm{Q}$ & 0.165 & 0.366 & 0.715 & & & & \\
\hline & $\mathrm{F}$ & -0.053 & -0.103 & 0.918 & & & & \\
\hline & $D$ & 0.537 & 1.079 & 0.283 & & & & \\
\hline & ADT & 0.619 & 0.663 & 0.509 & & & & \\
\hline & $C A D$ & 0.438 & 0.506 & 0.614 & & & & \\
\hline & QAD & -0.206 & -0.222 & 0.824 & & & & \\
\hline & FAD & 0.091 & 0.119 & 0.906 & & & & \\
\hline & DAD & -0.707 & -0.924 & 0.358 & & & & \\
\hline
\end{tabular}

Sumber: Data diolah

\section{SIMPULAN}

Hasil pengujian hipotesis tentang pengaruh pemoderasian hard technology dan soft technology terhadap hubungan strategi manufaktur dan kinerja perusahaan menunjukkan bahwa variabel adopsi hard technology memoderasi hubungan antara pilihan strategi manufaktur dengan kinerja perusahaan. Variabel adopsi hard technology disimpulkan sebagai variabel quase moderator. Sedangkan hasil pengujian hipotesis tentang pengaruh pemoderasian soft technology terhadap hubungan strategi manufaktur dan kinerja operasional tidak terbukti, atau dengan perkataan lain variabel soft technology berpengaruh terhadap kinerja operasional tetapi bukan merupakan variabel yang memperkuat atau memperlemah hubungan antara strategi manufaktur dan kinerja operasional.

Hasil penelitian untuk perusahaan manufaktur dilndonesia menunjukkan bahwa pengembangan dan implementasi strategi manufaktur tanpa didukung aplikasi teknologi baik hard technology maupun soft technology, tidak memberikan pengaruh yang signifikan pada kinerja operasional. Tetapi dengan melakukan adopsi teknologi baik hard maupun soft technology yang 
diaplikasikan dalam perusahaan memberikan dampak yang signifikan pada kinerja operasional perusahaan. Hal ini dikarenakan aplikasi teknologi memberikan kesempatan baru bagi perusahaan untuk lebih inovatif dan responsif terhadap dengan memperbaiki cara suatu produk atau jasa didesain, dikembangkan dan dijual dalam pasar. Aplikasi teknologi dalam kegiatan operasional perusahaan memberikan manfaat bagi perusahaan untuk dapat memperbaiki kualitas, fleksibilitas, kapabilitas pengiriman, bahkan pencapaian biaya produksi yang rendah dengan cara mengurangi tingkat kerusakan atau kegagalan produk sehingga dapat mengeliminasi atau paling tidak menurunkan "sampah" atau produksi yang tidak memberikan nilai guna.

Berdasarkan hasil penelitian yang diperoleh, perusahaan manufaktur di Indonesia umumnya lebih menekankan pada strategi kualitas dan biaya rendah. Oleh karena itu dukungan aplikasi atau adopsi teknologi baik hard technology maupun soft technology sangat diperlukan. Hal ini mungkin bertentangan dengan strategi biaya rendah yang diimplementasikan perusahaan, karena investasi dan adopsi teknologi khususnya hard technology memerlukan biaya yang besar pada saat perusahaan melakukan investasi tersebut. Tetapi perlu dipertimbangkan bahwa dalam jangka panjang aplikasi teknologi tidak hanya bermanfaat dalam menurunkan tingkat kerusakan dan meningkatkan kualitas produk, tetapi juga menurunkan biaya produksi per unit. Selain adopsi hard technology, perusahaan perlu juga melakukan adopsi soft technology karena terbukti bahwa dengan melakukan praktik-praktik manajemen modern seperti JIT, TQM, MRP, dan TPM perusahaan dapat memperbaiki kinerja manufaktur.

Implementasi strategi manufaktur perusahaan akan memberikan dampak yang signifikan bagi pencapaian kinerja perusahaan yang baik dengan dukungan aplikasi hard technology maupun soft technology yaitu praktik-praktik manajemen dengan catatan, keefektifan adopsi teknologi tersebut tidak hanya memerlukan keberadaan fasilitas produksi yang baru tetapi juga pengetahuan dan keahlian untuk mengimplementasikan perubahan teknis tersebut.

Berdasarkan fenomena temuan dalam penelitian ini, hal yang bisa digaris bawahi. adalah hard technology memoderasi hubungan antara strategi manufaktur dan kinerja operasional sebagai quase moderator. Sebaliknya soft technology mempengaruhi hubungan antara strategi manufaktur dan kinerja operasional sebagai independent predictor variable tetapi tidak memoderasi hubungan strategi manufaktur dan kinerja operasional. Selanjutnya peneliti mengakui sejumlah keterbatasan dalam penelitian ini yang mungkin dapat menimbulkan gangguan hasil penelitian. Pertama, jumlah perusahaan yang terlibat dalam penelitian ini masih dianggap sedikit sehingga model dan hasil belum dapat digeneralisasi, mengingat besarnya populasi perusahaan manufaktur di Indonesia. Kedua, peneliti hanya menggunakan persepsi CEO dalam menjawab pertanyaan-pertanyaan kuesioner, sehingga tidak terdeteksi apakah bidang-bidang langsung yang terkait dengan proses adopsi teknologi memiliki persepsi yang sama terhadap strategi manufaktur dan tingkat adopsi teknologi yang dilakukan perusahaan.

Beberapa implikasi manajerial yang dapat disimpulkan dari hasil penelitian ini meliputi: Pertama, Kesuksesan perusahaan dalam kondisi lingkungan bisnis yang tidak pasti akan tercapai jika perusahaan mampu memfokuskan pada prioritas kualitas, fleksibilitas, dan pengiriman. Hal ini dikarenakan kesuksesan perusahaan sangat ditentukan oleh kemampuan perusahaan dalam memenuhi kebutuhan dan kepuasan konsumen. Oleh karena kemampuan memproduksi produk berkualitas tinggi, kemampuan merespon perubahan dalam selera maupun permintaan, dan kemampuan dalam memberikan layanan dan pengiriman tepat waktu merupakan kunci kesuksesan perusahaan dalam persaingan bisnis. Kedua, untuk tetap dapat bertahan bahkan sustained dalam persaingan, perusahaan harus mampu merespon kebutuhan konsumen secara cepat dan fleksibel. Untuk itu perusahaan perlu melakukan adopsi teknologi karena kesuksesan perusahaan tidak hanya ditentukan oleh kemampuan memperbaiki kapasitas produk tetapi juga kapabilitas teknologi.

Ketiga, keefektifan dalam adopsi teknologi memerlukan tidak hanya fasilitas produksi baru tetapi juga pengetahuan dan keahlian untuk mengimplementasikan perubahan teknis. Kesuksesan 
perusahaan tidak hanya ditentukan oleh teknologi tetapi juga dari "people integrated manufacturing" yaitu keterkaitan erat antara hardware technology dengan ketrampilan yang melekat dalam diri manusia (human-embedded skills). Keempat, satu faktor kunci kesuksesan perusahaan manufaktur Indonesia untuk mencapai sustainabilitas perusahaan adalah bagaimana merubah paradigma dari "factory as a loboratory" menjadi "factory as a learning environment" untuk mensosialisasikan dan mengkomunikasikan adopsi teknologi sehingga dapat diperoleh kemanfaatan adopsi tersebut.

Kelima, adopsi hard technology yaitu AMT dan juga computer-based technology di Indonesia masih relatif rendah. Sehingga, mengherankan jika banyak faktor kegagalan perusahaan yang disebabkan oleh rendahnya adopsi dan implementasi teknologi. Soft technology seperti TQM, JIT, MRP, dan TPM, lebih diprioritaskan di Indonesia dibandingkan hard technology mengingat adopsi teknologi ini memerlukan biaya yang relatif lebih rendah. Soft technology dianggap lebih mudah diadopsi karena perusahaan dapat melakukannya secara bertahap dengan melakukan praktik-praktik manajemen modern, tanpa harus mengeluarkan biaya yang besar seperti dalam adopsi hard technology.

\section{DAFTAR PUSTAKA}

Aggarwal, S., (1995), "Emerging Hard and Soft Technology: Current Status, Issues and Implementation Problem", International Journal of Management Science, 23 (3): 323-339.

Autioe, A., dan Lemanen, T., (1995), "Measurement and Evaluation of Technology Transfer", International Journal of Technology Management, 10: 643-664.

Badri, M.A., Davis, D., dan Davis, D., (2000), "Operation Strategy, Environment Uncertainty, and Performance: A Path Analytic Model of Industries in Developing Country, Omega", International Journal of Management Science, 28: 155-173.

Beaumont, N.B. dan Schroeder, R.M., (1997), "Technology, Manufacturing Performance, and Business Performance Among Australian Manufacturers", Technovation, 17 (6): 297-307.

Braglia, M., Petroni, A., (2000), "Toward A Taxonomy Of Search Pattern Of Manufacturing Flexibility In Small and Medium Sized Firm", Omega, 28: 195-213.

Burgess, T.F., Gules, H.K. Gupta, J.N.D., dan Tekin, (1998), "Competitive Priorities, Process Innovations and Time Based Competition In The Manufacturing Sectors Of Industrializing Economies: The Case Of Turky", Benchmarking for Quality Management and Technology, 5 (4): 304-316.

Butcher, P., Lee, G., dan Sohal, A., (1999), "Lesson For Implementing AMT: Some Case Experiences With CNC In Australia, Britain and Canada", International Journal of Production and Operation Management, 19 (5): 515-526.

Das, A., Narasimhan, R., (2001), "Process-Technology Fit and Its Implication For Manufacturing Performance", Journal of Operation Management, 19: 521-540

Demeter, K., (2003), "Manufacturing Strategy and Competitiveness", International Journal of Production Economics, 81: 205-213. 
Ellitan, L., Jantan, M., dan Dahlan, N., (2003), "The Integrative Effect Of Hard and Soft Technology On Firm's Performance: An Empirical Study From Indonesia", 5th Asian Academy of Management Conference, $10^{\text {th }}-13^{\text {th }}$ September, 2003: 255-264

Galbraith, C dan Scendel, D., (1983), "An Empirical Analysis of Strategy Types", Strategic Management Journal, Vol. 4: 153-173.

Gerwin, D., (1993), "Manufacturing Flexibility: A Strategic Perspective", Management Science, 39: 395-410.

Gordon, J., dan Sohal, A., (2000), "Manufacturing Practice and Competitive Capability: An Australian Study", Technovation, 19: 295-304

Ghozali, I., 2002. Aplikasi Analisis Multivariate dengan Program SPSS". Badan Penerbitan Universitas Diponegoro Semarang, edisi 2.

Hair, J.F., Anderson, R.L., Tatham, dan W.C., Black, (1988), Multivariate Data Analysis, 5th ed., Upper Saddle River, New Jersey, Prentice Hall, Inch.

Heizer, J., dan Render, B., (2004), Operation Management, Seventh Edition Pearson Education International.

Hitt, M. A., dan Palla K.A., (1982), "Industrial Firm's Grand Strategy and Functional Importance: Moderating Effects Of Technology and Uncertainty", Academy of Management Journal, 25 (2): $265-298$.

Krawjesky, L.J., dan Ritzman, L.P., (2002), Operation Management: Strategy and Analysis, Sixth Edition. Prentice-Hall International, Inc.

Lagace, D., dan Bourgault, M., (2003), "Linking Manufacturing Improvement Programs To Competitive Priorities of Canadian SMEs, Technovation, 23: 705-715

Leong, G.K., Synder, D.L., dan Ward, P.T., (1990), "Research In The Process and Contend Of Manufacturing Strategy", Omega, 28: 109-122.

Nash,. M., (1984), Managing Organizational Performance, San Fransisco: Josey Bass Publisher.

Schroeder, R., dan Sohal, A.S., (1999), "Organizational Characteristics Associated With AMT Adoption: Towards A Contingency Framework", International Journal of Production and Operation Management, 19(12): 1270-1291.

Skinner, W., (1969), "Manufacturing-Missing Link In Corporate Strategy", Harvard Business Review, May-June: 136-146.

Small, M.H., dan Chen, I.J., (1995), "Investment Justification Of Advanced Manufacturing Technology: An Empirical Analysis", Journal of Engineering and Technology Management, 12: $27-55$. 
Sohal, A.S., dan Terziovsky, M., (2000), "TQM In Australian Manufacturing: Factor Critical To Success", International Journal of Quality and Reliability Management, Vol. 17(2): 158167.

Sulaiman, M., Hashim, M.K., dan Wafa, S.A., (2003), "Examining The Moderating Role Of Technology and Environment On The Business Strategy and Performance Relationship In SMEs", 5th Asian Academy of Management Conference, $10^{\text {th }}-13^{\text {th }}$ September, 2003: 265 276.

Swamidass, P.M., dan Newell, W.T., (1987), "Manufacturing Strategy, Environmental Uncertainty and Performance: A Path Analytic Model", Management Science, 33 (4): 509-524.

Tsang, A.J.H., dan Chan, P.P., (2000), "TPM Implementation In China: A Case Study", International Journal of Quality and Reliability Management, Vol. 17(2): 144-157.

Warnock, I., (1996), Manufacturing and Business Excellence: Strategies, Techniques, and Technologies, Prentice Hall Europe.

Ward, P.T., Bickford, D.J., dan Leong, G.K., (1995), "Business Environment, Operation Strategy, and Performance: An Empirical Study Of Singapore Manufacturers", Journal of Operation Management, 13 (2): 99-155.

Ward, P.T., dan Duray, R., (2000), "Manufacturing Strâtegy In Context: Environment, Competitive Strategy, and Manufacturing Strategy". Journal of Operation Management, 18: 123-138.

Wheelwright, S.C. dan Hayes, R.H., (1985), "Competing Through Manufacturing", Harvard Business Review, January-February: 99-109

Yasin, M.M., Small, M., dan Wafa, M.A., (1997), "An Empirical Investigation Of JIT Effectiveness: An Organizational Perspective, Omega: International Journal of Management Science, 25: 461-471. 